\title{
Ending The Honeymoon: Constructing Europe Beyond The Market
}

VB verfassungsblog.de/ending-the-honeymoon-constructing-europe-beyond-the-market/

Moritz Hartmann Do 8 Mrz 2012

Do $8 \mathrm{Mrz}$

2012
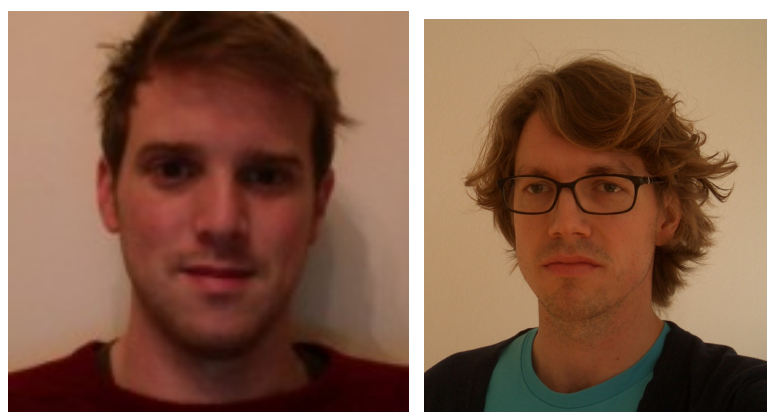

By MORITZ HARTMANN and FLORIS DE WITTE

In Greek mythology, King Sisyphus becomes a prisoner of inevitability: existentially condemned to roll a boulder up a hill for the sake of seeing it roll back down immediately. His sense of desperation and futility is reminiscent of Europe today. It has become a prisoner of the circularity of stabilising inherently unstable markets. And each cycle exacerbates the dominance of the economic over the political, the erosion of democratic paradigms, the indifference of citizens, and the divorce between social reality and its political translation. Political discourse is suspended while 'technocrats' redistribute resources and aspirations in the name of economic necessity. And we - the Europeans are sidelined and numbed by the repetitive talk of austerity and economic stability, EFSF and eurobonds, financial leverage and institutional reforms. All presented as inevitable for the health of the market; as a bitter medicine required to cease the pain. Needless to say, it will not: the pain is systemic.

For the younger generation of Europeans, the 'inevitable' changes instituted in the past years will define our future. That is why it is time to take a stand. Our lives cannot be shaped as a by-product of economic stability. The European Union is more than a market. Its citizens are more than consumers. Our political choices should make the market socially acceptable; the market should not make our political choices economically acceptable. Our generation has ideas, ideals, hopes, needs and aspirations. And we strongly believe in Europe, just not in this particular economic manifestation of it.

We believe in Europe because we are Europe. We construct it today, and will do so tomorrow. In Lodz and Odense, Sevilla and Nicosia, one day perhaps in Split and Izmir. By travelling, by communicating, by working, by studying. The nation state might be our passport; Europe is our identity. On Ryanair flights, we are all Europeans. In Ukraine and Poland, next summer, we are all Europeans. We come together to celebrate what binds us as much as what divides us. We will speak in whichever language seems most appropriate. And we will do the same in London a few months later. Even at home, we are all Europeans. Our hairdresser is from Riga, the woman behind the counter of the espresso bar in Dublin is from Brno. We listen to a Belgian band on the French radio while eating a pizza in Goteborg. Our wine is Portuguese, our cheese Italian. Our favourite football player is born in Gelsenkirchen and plays in Madrid, and our university teacher in Groningen is originally from Helsinki. An open and free Europe was the dream of the previous generations. It is our reality.

Europe is more than economic rationalisation. Conceptualising Europe as a market belittles its citizens, its potential and its credentials. Its citizens are not one-dimensional consumers and market freedom winners; its potential is greater than the next rating by Standard \& Poor's; and its credentials require narratives beyond economic stability. It is time to change the European narrative, and to enrich the common understanding of Europe by a more coherent 
and public idea of what Europe can and should do.

We argue that the market's honeymoon in Europe must end, and we offer a new narrative towards which the European Union can direct its normative ambitions. We need to decode the singular understanding of Europe as a market, and construct its future beyond the market's rationale. A new Europe must be based on trust between its citizens, geared towards the aspirations of its younger generations, and capable of generating a public discourse on its trajectory. In order to prevent our generation from being lost in the inevitability and circularity of the market, we need to snap out of our own reality and fundamentally question who we are, what we want and how we can actually achieve it.

\section{Trust}

Despite the European Union's own metamorphosis from a post-war economic facility to a supranational body of great institutional, political and economic power, and despite the ever greater numbers of citizens who are faced with the daily reality of free movement, the Union's operating code has remained decisively economic. European integration is mainly understood as a successful mode of integrating national economic diversity. But what sustains the idea of Europe is not just economic homogeneity. What sustains Europe is the cultural diversity and trust which we experience on a daily basis through interactions which we have in the job centre in Brussels and in the Turkish supermarket in Linz, with the bus driver next to the lake in Annecy as well as with the barista in the port of Naples. Trust reduces the systemic complexity of Europe, and stabilizes both the market and the project of European integration more than any regulatory program of the Commission.

We do not argue for a substitute to global markets nor the elimination of market dynamics altogether. Rather, we argue for a paradigmatic shift: from a view that embeds the European project in its economic straightjacket to one which embeds it in a continental matrix of inter- and intra-generational trust. As the crumbs of the market will be eaten, the Europe which we face will have to be based on trust. The European Union must learn to capitalize on that trust. So far, it has allowed markets to internalize both individual and institutional trust for the sake of maximizing their returns. The Union needs to reverse that process: it needs to extrapolate its legitimacy from the trust between its citizens. Because it is trust, and not market integration, which is at the source of the social cohesion and ethnic tolerance, fairness, solidarity and diversity which characterizes Europe. Before we trust in Europe's normative premises, in its economic capacities and its institutions, we need to make sure that it, in reciprocity, is able to put the potential that lies in the inter-personal trust between its citizens to good use.

\section{Aspirations}

If Europe is to be relevant for our generation, and our generation to be relevant for Europe, we need to move beyond the defeatist hollowness of market stability and embrace the aspirational possibilities of a united Europe. In 1956, the creation of the EEC was an aspirational project. While originally conceived to take the sting out of nationalism, and to encourage the economic growth of a shattered continent, neither the promise of 'peace' nor that of 'prosperity' seem (in 2011) to generate the popular legitimacy which the EU so craves. This is not to question its historic relevance and success. Rather, it is a concern that this particular institutional manifestation seems to consume more goodwill than it produces.

At this moment, the only 'European dream' offered to our generation seems to centre around a lifetime of debt repayment and austerity, less opportunities on the labour market than ever before, stripped down welfare systems and hollow rhetoric in the effort of saving our planet. Simply put, we need Europe to meet the aspirations of our generation on top of the aspirations of its founding fathers (and mothers). In order to do so, proposals as simple as offering language courses or as complicated as communal energy security through green technology must be pursued. Such proposals meet the aspirations of our generation: that of personal development through movement, new labour possibilities, and a sustainable world. And it allows the Union to become, once again, the aspirational 
forum that is embraced by the younger generations as providing a powerful idea of how to make our societies and our world a better place. The EU can help us to aspire for more. But it needs to stop churning out measures of economic rationalisation without making an effort to embrace a stronger normative vision of, and contribution to, our future.

\section{Public}

Our history was national, our present is increasingly European, and our needs and aspirations are ever more of a transnational character. The economic processes dictating our lives are global. Yet our political system remains national. It is this asymmetry between social reality and political structures which allows for the dominance of the economic over the political, of the executive over the parliamentary, and which thereby allows the market to anonymise its founding social capital: the trust between citizens. The asymmetry is so entrenched and systemic that markets can, these days, overthrow governments. But were politics not meant to tame and humanize the markets, rather than the other way around?

In order to re-assert our capacity to control how we want our societies to function, we need to deconstruct our understanding of the public. Politics only function by grace of a direct link between reality and fantasy. All political claims are fantasies: projections of how the future can be better or more just. And the role of politics is to translate those fantasies into reality. At the moment, however, we seem to be barking up the wrong tree. While the national political system remains invaluable in the redistribution of resources, it is no longer capable of constraining the economic system to ensure that it leads to socially acceptable outcomes. It is incapable of securing our aspirations and needs beyond the nation state. Yet we continue to articulate our fantasies towards national political systems. In doing so, we entrench the status quo and allow the national executive to hide behind 'national interests' when discussing our transnational needs and aspirations, and enable the sidelining of representative institutions under the guise of inevitability.

If we want to re-assert the dominance of the political over the economic we need a European political space in which decisions are explained, fantasies articulated, and Europe's trajectory discussed. A space which can capture the trust between its citizens and can meet their needs and aspirations. And a space whose leaders can be changed when it fails to do so. The reassertion of the public requires institutional and normative rebalancing. In institutional terms, we should move towards the establishment of European political parties, towards European Parliament elections in which each of these parties proposes a candidate Commission president, and towards a diminished influence of the European Council in setting out the political trajectory of the EU. Such changes would galvanize the transnational political discourse and introduce dynamic partisan politics at the heart of the decision-making process. But such changes will not be proposed by national politicians, who stand to lose most in the vast re-enfranchisement of the voice of the European citizens. Instead, it requires those citizens to reach beyond the boundaries and create a common, multi-lingual, public space on the transnational level: where ideas are exchanged, fantasies formed and articulated, and where politicians are forced to take notice.

\section{Onwards}

Condemned by the Gods, King Sisyphus' predicament was eternal. For us, it does not have to be. But if we want to escape from the market's circularity, we need to re-assert who we are, what we want, and how we can actually achieve it. None of these questions can be convincingly answered by national political arrangements, nor by the EU as it is now. This incapacity has allowed the economic system and the executive army of technocrats to take control of the citizens, no longer protected by the dominance of politics or representative parliaments. But Europe is more than a market. It has the potential to solve the systemic problems which are at the origin of our current economic, ecological and political crisis. But we, its citizens, may have to force it to actually do so. 
Europe conducted by Moritz Hartmann (PhD researcher at the Freie Universität Berlin) und Floris de Witte (PhD researcher at the London School of Economics and Political Science).

LICENSED UNDER CC BY NC ND

SUGGESTED CITATION Hartmann, Moritz: Ending The Honeymoon: Constructing Europe Beyond The Market, VerfBlog, 2012/3/08, http://verfassungsblog.de/ending-the-honeymoon-constructing-europe-beyond-the-market/. 